\title{
Research on College English Curriculum Reform in Technical Colleges and Universities under the Guidance of College English Teaching Guide: the Compilation of College English Teaching Materials
}

\author{
Siyou Zhang ${ }^{1}$, Chunli Liu ${ }^{1}$ \\ ${ }^{1}$ City College, Wuhan University of Science and Technology, Wuhan, Hubei Province, China
}

\begin{abstract}
Keywords: Technology-Applied Undergraduate Courses; College English Teaching; Teaching
\end{abstract} Material Compilation.

\begin{abstract}
In order to cultivate applied talents required for social and regional economic development, in 2014, the state proposed that some undergraduate colleges and universities should be guided to transform into technology-applied universities. Then, in 2015, the English Language Teaching Advisory Board under the Ministry Education Ministry issued College English Teaching Guide, which clarified the orientation and nature of college English curriculum. Therefore, it is imperative to reform college English curriculum. Curriculum reform begins with teaching, while teaching cannot be realized without teaching materials. Therefore, it is urgent to compile college English teaching materials which are suitable for the cultivation of technology-applied undergraduates. The author believes that, in order to design excellent college English teaching materials in the new period, we must first determine the principles of teaching material compilation which should conform to the national development strategies and the standards of higher education reform; then we need to work on the designing ideas of teaching material compilation, which should combine instrumentalism with humanism; afterwards, college English teaching materials should be edited on the basis of students' job orientations, in order to improve students' working abilities and employment competitiveness. College English teachers can participate in the compilation. We also need to develop open college English teaching materials and establish data service platform.
\end{abstract}

\section{Introduction}

In June 2015, the State Council issued the Decision on Accelerating the Development of Modern Vocational Education (Guo Fa [2014] No. 19), pointed out that in 2020, China should establish a "world first class modern occupation education system with Chinese characteristics"; some ordinary undergraduate universities should transform to technology-applied colleges and universities; the connection system of courses should be established and improved; occupation ethics and humanistic quality education should be embodied in the whole process. Under the guidance of national education policies, College English Teaching Guide (hereinafter referred to as the Guide) was issued to further deepen the reform of college English teaching and training, and to improve the quality of teaching and learning. The Guide orientates college English as curriculum which includes both instrumental and humanistic features. Therefore, it is imperative to reform the college English curriculum in technology-applied colleges and universities. Curriculum reform begins with teaching, while teaching cannot be realized without teaching materials. Therefore, it is urgent to compile college English teaching materials which are suitable for the cultivation of technology-applied undergraduates. Therefore, it is imperative to compile college English teaching materials which combine the transformation and development trends of applied undergraduate colleges with the new orientation of technology-applied college English curriculum under the Guidance.

\section{Requirements on Personnel Training in Technology-applied Colleges and Universities}

At present, China's vocational education cannot fully meet the needs of economic and social development. The education structure is unreasonable and low quality. With the development of national and regional economies, the demands for talents are diversified, while technology-applied 
talents are urgently needed. In addition, in 2020, we need to establish a "world first class modern occupation education system with Chinese characteristics". Under such conditions, technology-applied undergraduate colleges and universities come into being. Their responsibility is to speed up the training of high-quality technical personnel to meet the needs of economic and social development in the new times.

The students of technical colleges are still in the stage of "school people". They must go through the process of "two changes": socialization and professionalization. In the socialization process, students need to learn how to become a "social person", since they need to participate in social and economic life, learn social norms, fulfill their social obligations, get self understandings and obtain social recognitions after entering the society. In the process of professionalization, students need to become a "professional person" and strive for successful employment and better lives after graduation. A position in work place does not only mean guarantee of sustenance; it also reflects the social recognized identity and an opportunity to realize self value and comprehensive development.

In order to achieve the goal of cultivating applied technical undergraduate talents, we must establish a set of effective teaching system first. As a part of the college teaching system, the teaching concept of English curriculum should be changed. Teachers need to focus on improving students' abilities of using English, as well as their communicative abilities, work competitiveness and development abilities. The course should be improved from the perspectives of humanism and cultivating students' quality of handling change in employment market, so as to promote the cultivation of high-quality technical talents with social and occupation abilities, meet the requirements of economic and social development and national development strategies.

\section{Practical and Humanity Values of College English Curriculum}

As a kind of language, English is a tool of thinking, communication and cultural transmission. But it is different from general tools, since language also has humanity values. The word of humanity not only reflects the core and essence of human culture, but also emphasizes human beings as the main body. Language is the carrier of cultural heritage; it has humanity values, for it reflects the respect and care for people.

Since the language has both practical and humanity values, the college English teaching should reflect practical and humanity values, too. The Guide clearly points out that, the practical values of college English curriculum means college English courses should "promote the development of English teaching in the stage of basic education to further improve students' abilities of listening, speaking, reading, writing and translating. Through learning knowledge related to their future works, students' communication abilities in academic and occupation fields should also be strengthened". The humanity values mainly reflect in "people-oriented cross culture education, promotion of human value, and great attentions to students' quality cultivation and comprehensive development". The aims of college English course not only include the improvement of students' comprehensive humanistic qualities, but also include the emphasis on students' overall development.

\section{The Compilation of College English Teaching Materials}

Meeting the needs of national development strategy and education reform. In the new period, the integration of global economy, the change of social employment standards and the demands of national development strategy have promoted the development and reform of higher education. As a compulsory course in applied technical colleges, college English teaching reform has become an inevitable trend. [1] The macro design of college English teaching materials should accord with the transformation and development spirit of central and local governments, trying to meet the needs of national development strategy and the development of modern higher education, considering the necessity of school training, developing teaching materials target to social development trend and market demands.

Publishing and compilation team should be keenly aware the trends of college English curriculum reform, trying to meet the requirements of technology-applied talents training, exploring new ideas 
and new markets. As parts of the economic society, publishing houses and the educational circle should bear corresponding social responsibilities. In order to implement national policies of publishing, reforms on teaching contents and the publication of teaching materials should be promoted to cultivate high-quality technical talents.

Combining practical and humanity values organically. The Guide defines college English as courses with both practical and humanity values. This definition is not only the guidance for college English courses, but also the orientation of college English teaching materials. [2]

Human growth and development cannot be realized without three elements: knowledge, ability and quality. College English teaching should reflect the unity of practical and humanity values, stick to the principle of "applicable, practical and easy to use", and arrange teaching content in accordance with knowledge, abilities and comprehensive qualities required by the society and occupation fields.

After selecting topics, the specific content in each unit should be edited on the bases of language knowledge and skills required by workplace. The combination of practical and humanity values is required to carry on the reform of college English curriculum, strengthen the practicality of courses, and bring potential energy to the curriculum. In this way, training of high-quality technology-applied talents could be promoted.

Emphasizing students-centered conception. Human care emphasizes human beings, pays attention to the development of human beings, and highlights the needs of human beings. [3] Regarding teaching materials, humanity care means to take students as the center, pay great attention to their individual development, as well as their physical and mental health, in order to satisfy their demands on study and their future development.

Most of college students born in 1990s are independent. They are brave but cannot endure hardship; they have personalities but are lack of rule consciousness; they have potential but are utility. In view of these characteristics, college English teaching materials should respect students' personalities, stimulate innovation, and encourage them to discover and solve problems. Teaching materials should be student-centered, trying to explore students' personalities and potential; they also should promote the change of teachers' roles, creating target and task driven teachers in classrooms. Good teaching materials can help teachers to fully mobilize the enthusiasm of students, and encourage students to participate in activates. Interactions and mutual assistance between teachers and students can be realized. Through this mutual learning process, students and teachers can make mutual improvements.

Developing open teaching materials. At present, about 95\% college English teaching materials in China are closed. [4] These textbooks create closed systems, and do not have high flexibility. A full set of books must be selected at the same time. These books are distinguished based on difficulties of language. Combining the "two changes" of technology-applied undergraduates, open teaching materials should be developed and published. College English teaching materials should be divided into three stages to conform the "three goals" proposed by the Guide. The three goals are basic goal, improvement goal and development goal.

In the first stage, the development and preparation of basic English teaching materials are needed. Humanities topics should be focused to improve students' language skills and humanistic quality. Proper work and occupation related topics should also be included in teaching content. In the second stage, business English in the workplace and general topics should be focused to improve students' communicative abilities. Career related and humanities topics should be deepened to realize quality education, and help students to better adapt workplace. In the third stage, business English should be focused to enhance students' professional and academic abilities, enable them to become occupation people.

The third stage is open. Teaching materials should be prepared according to the actual needs. They should advance with the times, and meet the needs of various industries, especially the requirements of new industry on high-end technical personnel with foreign language abilities. Teaching materials of the three stages complete a development system, while college teachers can select any one or two stages according to the requirements of curriculum and the limitation of teaching hours to achieve teaching goals with flexibility. 
Participation of college English teachers. Teachers are the main body of using teaching materials and implementing the whole process of teaching. They are familiar with the real situation of teaching, the overall expectations of teachers, as well as students' English abilities and their development needs. Meanwhile, college English teaching materials ought to meet the needs of teaching and learning. Therefore, elite teachers should participate in the development of teaching materials to create high quality teaching materials which can meet the needs of students and national education development strategies.

Publishing companies and the compilation team can follow up the usage situation of teaching materials and organize teachers' discussion. By collecting all kinds of information, and comprehensively analyzing and classifying the information they collected, publishing companies and the compilation team can get fully understanding of the teaching materials' usage situation. The classification of feedback information can be carried out from the aspects of advantages and disadvantages of current teaching materials, the needs and expectations of teachers, and students' learning needs. Compilation plans should be made after communication with teachers. Publishing companies and the compilation team also need to pay attention to user needs and expectations, actively look for improvement and innovation methods, and establish two-way communication channels which contribute to teachers and themselves. [5]

Establishing big data platform of college English teaching materials. In the age of Internet, the widely use of big data leads to a reform of publishing industry, provides new teaching media, new teaching platform, network teaching materials, and three-dimensional teaching materials. New teaching methods like MOOC classes and micro classes are created on the bases of network and multimedia. Publishing companies and the compilation team can go into universities, investigate the needs of students and teachers, use diversified platforms to provide various teaching and learning resources, in order to satisfy the needs of teachers and students to the largest extend.

First, an open database should be established. College English teachers can use the data base to collect data on teaching and researching. Secondly, a network communication platform for teachers should be established. The platform can use big data on network media to promote the exchange of publishers and teachers, and encourage a wide range of teachers to learn and share teaching resources. Furthermore, series of micro courses or MOOC classes can be developed to promote the effective development of classroom teaching and students' autonomic learning.

To sum up, the actual needs of national economic and social development brings the transformation of technology-applied colleges and universities; the promulgation of Guide promotes the reform of college English teaching. In the process of compiling new teaching materials, we should pay attention to training needs of technology-applied talents, the teaching process of teachers, as well as the learning and development requirements of students, in order to develop high quality English teaching materials for technology-applied colleges and universities. Only in this way, can we cultivate high-quality technical talents, and meet the requirements of national development strategy and regional economic development. [6]

\section{Acknowledgement}

Fund Project: This project is supported by Foundation for Provincial Teaching Research Projects of Hubei, 2015. Project number: 2015461.

\section{References}

[1] X.J. Li, Existing problems and countermeasures on the publication of college English teaching materials, J. Editorial Friend. 3 (2012).

[2] C.Y. Gan, Analyses on the current situation of Chinese college English teaching and the guiding significance of College English Teaching Guide, J. College English Teaching and Research. 3 (2016).

[3] Y.Q. Xiao, The study of English teaching materials publication under the background of educational reform, J. A Vast View on Publishing. 12 (2015). 
[4] B. Yang, Research on the trend of college English teaching material compilation, J. China Publishing Journal. 14 (2011)

[5] B.Y. Yu, The development direction of college English teaching materials under the framework of foreign language teaching integration, J. Computer-assisted Foreign Language Education.11 (2010).

[6] S.R. Wang, Interpretation of main points in College English Teaching Guide, J. Foreign Language World. 3 (2016). 